\title{
Students' Writing Ability on Islamic Narrative Text Topic
}

\author{
Sri Rahmadhani Siregar \\ Institut Agama Islam Negeri Padangsidimpuan \\ E-mail: srirahmadani@iain-padangsidimpuan.ac.id,
}

\begin{abstract}
Abstrak
Penelitian ini fokus kepada kemampuan menulis siswa dalam topik teks naratif islami kelas 11 di MA An-Nur Padangsidimpuan. Penelitian ini diselesaikan melalui penelitian kuantitatif. Ada 11 murid sebagai sampel dalam penelitian ini. Kemampuan siswa diukur dengan memberikan mereka test essay dengan menulis tentang topic yang islami seperti kisah cerita nabi dan sebagainya. Data dianalisis dengan menjumlahkan nilai rata- rata dari murid untuk menentukan kategori dari kemampuan murid. Berdaarkan hasil dari penelitian, nilai rata- rata dari murid adalah 75.09. Itu artinya, kategori kemampuan siswa tergolong ke dalam kategori yang bagus.

Kata Kunci: Kemampuan Menulis, Teks Naratif, Topik Islami.
\end{abstract}

\begin{abstract}
The research focused on students' writing ability on Islamic narrative text topic at XI grade students MA An-Nur Padangsidimpuan. It was done through quantitative research. There were 11 students as samples of the research. The students' ability was measured by giving them essay test in writing about Islamic topic such prophet story. The data was analyzed by calculating students' mean score to decide students' ability category. Based on the result of research, students' mean score was 75.09. It means that, the students' ability categorizes into good category.

Keywords: Writing Ability, Narrative Text, Islamic Topic.
\end{abstract}

\section{INTRODUCTION}

Writing is ability of students to express their idea to become a piece of good written text by following procedure and rules of text. Writing is the way to share and deliver our idea in our brain into writing language and writing also is tool of communication indirectly to express what is thought and felt (Fahmi and Rachmijati 2021) through written text (Fahmi and Rachmijati 2021). Moreover, writing is the activity most often carried out by students in school because all lessons must use writing as a means of transferring information (Saputra et al. 2021) and made in written expression, tests and examinations, (Okome, Danner, 
and Ofuani 2021). Therefore, writing skill are supposed to be one of the most difficult language skills for students to master. Based on Mora-Flores in Fajrina, writing is a process by which we transfer our thinking, our ideas, and our experiences into written form. The process of writing is complex in which these processes should follow from its first step until the final step of writing (Fajrina 2017). By writing, we can share idea, thinking or experiences into good composition. Thus, students who want to be able to write a good writing, they have to learning to write regularly.

Students' in senior high school emphasizes on ability in writing a kinds of genre text. The 2013 curriculum has used text-based language learning, meaning that students are required to be able to produce a text (Kaffah, Rohaeti, and Abdurrakhman 2021). Students required to be able to understand, to express information ideas, feeling and develop their knowledge on written communication (Jannah 2021) use correct grammar, punctuation and vocabulary (Fauziah, Friatin, and SUrahmat 2021). In fact, writing is essential skill that students need to have.

Actually, students will not be free from making mistakes in creating a piece of written text. The existence of writing rules based on the type of text makes students have difficulty in writing a text. The problems came from students and also from difficulties level of text. Based on previous observation, the problems come from students' less in vocabulary and interest to write. Each text has own difficulties to create based on the purposes of text, generic structures and language features.

Several related studies stated about Islamic narrative text topic is by Faridi \& Bahri, this study aims at producing a learning model in English reading Islamic narative texts for Islamic junior high schools in Central Java. The results of the experts' judgement and try out in the validation stage, this learning material model was valid to be used as the reading material for narrative story in Islamic junior high school in Central Java. Another studies also found in Ardianto. This study was intended to find out what materials which were needed by eighth grade of Islamic junior high school in Central java. The last finding indicated that the materials suited on students as they learned narrative texts while also incorporating Islamic values (Ardianto 2016). The next researcher also conducted her research. The aimed of the research is at the improvement of students writing narrative text. the findings indicated that there was an 
improvement in students writing narrative text from cycle I to cycle II (E. Aulia 2021). By those researches, it is important to investigate the students writing narrative text with Islamic topic.

One of required text in senior high school students is narrative text. As cited by (Alviano, Oktawati, and SY 2020) in Oshima and Hogue narrative text is story writing that talks about fiction and nonfiction story (Rahman et al. 2020). When we write narrative text, we write about events in the order that happen in the past. The genre of narrative is one of the most commonly read, although least understood of the other genres. Narrative is not only considered as entertaining a reader, but also it has a powerful medium for changing social opinions and attitudes (Sari and Susiani 2021). In sum, writing narrative text needs serious attention so that students are confident in expressing ideas.

Narrative is text type that tells about story whether true story (problematic personal experience) or fictional that has purpose to entertain or amuse the readers with the story (Khadafi 2017). According to Connelly \& Clandinin in Faridi and Bahri, Islamic narrative story is a narrative story that brings out Islamic stories. These stories are adapted or excerpted from stories existing in both the Koran Holy Book as well as Al Hadith. Based on both sources, Islamic narrative stories become rich of good moral value and provide good character education to the students (Faridi and Bahri 1967). In this case, Islamic narrative story has a good purpose that give a moral value to the Islamic students nowadays. As cited in (Ardianto 2016), studies which have Islamic values are assumes to have positive contribution to the success of the development of character education in Indonesia. So, the researcher wanted to know students' ability in writing narrative text by giving them Islamic topic.

\section{THEORETICAL DESCRIPTION}

Writing ability is a skill that emphasizes students to create a piece of written text based on topic given. Writing is one of subjects that students have to be mastered beside reading, speaking, and listening. Writing is a matter of describing the text in accordance with what the author can think is reasonable that the readers knows expects (Mufida 2020). Writing is the way to share and deliver our idea in our brain into writing language and writing also is tool of communication indirectly to express what is thought and felt through written text (Fahmi and Rachmijati 2021). According to Brown, writing is the nature of 
the composing process of writing. Written products are often the result of thinking, drafting and revising procedures that require specialized skills, skills that not every speaker develops naturally (Brown 2007). In sum, writing is a process of finding ideas to share understanding to the reader through sentence or paragraph. By doing writing activity, the author can give a reasonable written for the readers to know about the expects.

The next point of view that have to be discussed is narrative text, narrative is the representation of events, consisting of story and the story is an event or sequence of events (Abbott 2002). This is lined with Langan theory said that narrative is a simply story that illustrates a point, the point is often an emotion you felt (Langan 2006). Additionally, narrative means a story either spoken or written about related events, the part told in literary work, it is different from dialogue, and the practice of storytelling (Eliyawati, n.d.). In conclusion, narrative text is a text with story form that has structure by giving some sequencing events and can illustrates the emotion you felt.

Narrative is text type that tells about story whether true story (problematic personal experience) or fictional that has purpose to entertain or amuse the readers with the story (Khadafi 2017). According to Connelly \& Clandinin in Faridi and Bahri, Islamic narrative story is a narrative story that brings out Islamic stories. These stories are adapted or excerpted from stories existing in both the Koran Holy Book as well as Al Hadith. Based on both sources, Islamic narrative stories become rich of good moral value and provide good character education to the students (Faridi and Bahri 1967). In this case, Islamic narrative story has a good purpose that give a moral value to the Islamic students nowadays. As cited in Ardianto, studies which have Islamic values are assumes to have positive contribution to the success of the development of character education in Indonesia (Ardianto 2016). The development of text narrative can be improved by giving such this think to the English narrative written text.

\section{RESEARCH METHOD}

The research categorized into quantitative research. The samples of the research were 11 students at grade XI-1 MA Annur Padangsidimpuan for academic year 2020/2021. The research used test as instrument to evaluate students' ability in Islamic narrative text. The test was essay test and students had to create a narrative text from choosing a title Prophet Sulaiman, Prophet 
Nuh, and Qabil \& Habil. The data were calculated from students' answer sheet in writing narrative text. The data were analyzed by counting students' mean score and looking categorize table to decide the level of students' ability in writing.

\section{FINDINGS AND DISCUSSION}

Referring to the objectives of this research in which the writers aimed to find out the students' ability in writing Islamic narrative text at grade XI-1 MA Annur Padangsidimpuan, the findings of the data revealed the following result.

Table 1

Quality Score of Students' Writing Islamic Narrative Text

\begin{tabular}{cccc}
\hline \hline No & Students & Total score & Quality score \\
\hline \hline 1 & Students 1 & 79 & Good \\
\hline 2 & Students 2 & 90 & Very Good \\
\hline 3 & Students 3 & 67 & Enough \\
\hline 4 & Students 4 & 67 & Enough \\
\hline 5 & Students 5 & 74 & Good \\
\hline 6 & Students 6 & 60 & Enough \\
\hline 7 & Students 7 & 91 & Very Good \\
\hline 8 & Students 8 & 60 & Enough \\
\hline 9 & Students 9 & 75 & Good \\
\hline 10 & Students 10 & 84 & Very Good \\
\hline 11 & Students 11 & 64 & Enough \\
\hline
\end{tabular}

There is various quality of students from the result of writing Islamic narrative text. There are 3 students get very good quality, and 3 students on good quality and the rest on enough quality. After knowing the score for each student, it came to counting the mean score to know the category from all students. It is presenting in the following table.

Table 2

The Resume of Students' Score

\begin{tabular}{ccc}
\hline \hline No & Description & Statistics \\
\hline \hline 1 & Total & 811 \\
\hline 2 & High Score & 91 \\
\hline 3 & Lowest Score & 60 \\
\hline 4 & Mean Score & 75.09 \\
\hline 5 & Median & 74.6 \\
\hline 6 & Modus & 75.6 \\
\hline 7 & Range & 31 \\
\hline
\end{tabular}


Based on table 2, the result of students writing in Islamic narrative text have gotten mean score 75.09. It means that, the students' ability categorizes into good category. From all samples, the total score was 811 with consisted of the highest score was 91 and the lowest score was 60.

Then to know the description about classification or the criteria of mean score the ability of the XI-1 MA Annur Padangsidimpuan in mastering writing Islamic narrative test, the table is presented below:

Table 3

Frequency Distribution of Students' Score

\begin{tabular}{ccccc}
\hline No. & Interval & Mid Point & Frequency & Percentage $\%$ \\
\hline \hline 1 & $60-66$ & 63 & 3 & $27.27 \%$ \\
\hline 2 & $67-73$ & 70 & 2 & $18.18 \%$ \\
\hline 3 & $74-80$ & 77 & 3 & $27.27 \%$ \\
\hline 4 & $81-87$ & 84 & 1 & $9.09 \%$ \\
\hline 5 & $88-94$ & 91 & 2 & $18.18 \%$ \\
\hline & $\boldsymbol{i}=\mathbf{7}$ & & 11 & $99.99 \%$ \\
\hline
\end{tabular}

Based on table 3, the students' score in class interval between 60 - 66 was 3 students $(27.27 \%)$, interval class between $67-73$ was 2 students $(18.18 \%)$, interval class between 74 - 80 was 33 students (27.27\%), interval 81 - 87 was 1 student (9.09\%) and interval between 88 - 94 was 2 students (18.18\%).

In order to get description of the data clearly and completely, there are presenting the result in the following histogram:

\section{Histogram 1}

\section{The Students' Ability in Writing Islamic Narrative Text}

\section{Frequency}

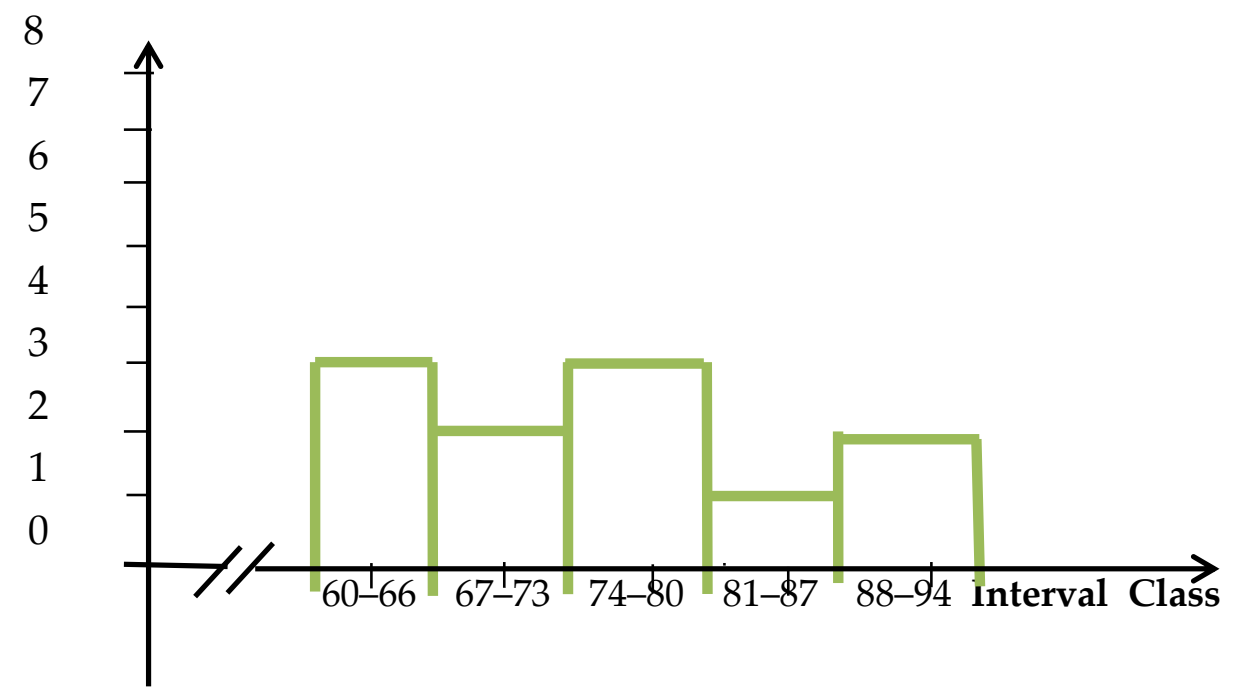


The histogram 1 is showing the students score based on the interval class. It can be seen the comparison between the highest score and the lowest score. The highest score was at interval 88-94 that came from $2(18.18 \%)$ students and the lowest score was at interval $60-66$ that came from $3(27.27 \%)$ students. The value of mean score was 75.09 that could be categorize into good category. It means that the students' ability in writing Islamic narrative text was good. In addition, the description data of students' ability in writing Islamic narrative text can be applied into the distribution frequency.

Moreover, to know the description about classification or criteria of mean score ability of the XI-1 grade students in ability writing Islamic narrative text in MA Annur Padangsidimpuan, it presented at the next table.

Table 4

Percentage of Students' Frequency Score in Writing Ability

\begin{tabular}{ccc}
\hline $\begin{array}{c}\text { Students range frequency } \\
\text { score (lowest to highest) }\end{array}$ & Amount of Students & Percentages \\
\hline \hline $60-66$ & 3 & $27.27 \%$ \\
\hline $67-73$ & 2 & $18.18 \%$ \\
\hline $74-80$ & 3 & $27.27 \%$ \\
\hline $81-87$ & 1 & $9.09 \%$ \\
\hline $88-94$ & 2 & $18.18 \%$ \\
\hline
\end{tabular}

Table 4 presented the frequency distribution about students' score in good category. The previous research has found that students' ability in writing narrative text categorize into good category by getting mean score 88,73 (F. Aulia 2019). She asked students to create a piece of writing narrative text and the result calculated in good score. She also asked the students to fill questionnaire to get answer how students' fell in writing narrative text and the result of students' answer was easy in writing narrative text. The same result again had found that students ability in writing narrative text categorize into good by getting percentage of mean score $78.82 \%$ (Hartati 2019). From this currently research and previous result of others, it can be stated that narrative text is not difficult to create by students because most of them can get good score from the test.

Actually, students' ability in writing narrative text also had been found in various level like high level, low level, very low until unable to write narrative text (Nurhidayah 2017). She has different result with this research about the 
categorize of students' ability in writing narrative text. In addition, (Mufida 2020) also found the same result that students' level in writing narrative text get in good level, fair level, low level and unable to write. She concluded that the students' ability in writing narrative text is still low level. Moreover, the different result from (Hasibuan and Handayani 2018) showed that most of the students are unable in writing narrative text. They evaluate students' ability in writing narrative text from content, organization, vocabulary, language use, and mechanics.

It this occasion, it can be afforded to reveal the real problems in which students got in creating narrative text with Islamic topic. It has conducted interview to the students and English teacher to get the data needed in supporting this research. The result of interview with students, it has found that the mayor problems was in vocabulary, generic structures and language features of the text. Those problems were not out of solution. The teacher made effort how to overcome students' problems. The teacher creates a table for each types of text and fill the table with generic structures and language features of text. The more students' practice to create a text, the more they remember all the text. As cited in (Ya-ning 2021) in the teaching of writing, teachers should not be entangled in the teaching of single vocabulary and grammar, but should pay attention to it. Text structure, vocabulary and grammar teaching aids the analysis of article structure, and the overall structure of the article helps students to add.

This is in line with the result of previous research (E. Aulia 2021) \& (Al'Imroah 2018) who found that students' problems in writing came from students' weakness in vocabulary so that students' get difficulties in expressing idea to write. Besides, (Mufida 2020) also had found that the big problems of students in writing narrative text is vocabulary. While, the different one came from the result of research that most of students think writing is difficult skill for them because they have limited understanding in vocabulary, grammar, tenses mastery (Hasibuan and Handayani 2018) and punctuation (Hartati 2019). There are so many text genres on students' materials in English. It is no easy to differentiate one another. Language features consists of grammatical structures of text. In fact, the students should remind which grammar was suitable with each kinds of text. 


\section{CONCLUSION}

According to the data analysis, the writer revealed that in students' writing narrative text through Islamic text topic categorized into good category. The students' score in class interval between 60 - 66 was 3 students (27.27\%), interval class between 67 - 73 was 2 students (18.18\%), interval class between 74 - 80 was 33 students (27.27\%), interval $81-87$ was 1 student $(9.09 \%)$ and interval between 88 - 94 was 2 students $(18.18 \%)$. 


\section{REFERENCES}

Abbott, H. Porter. 2002. The Cambridge Introduction to Narrative. The Edinburgh Building: Cambridge University Press. http://libgen.rs/.

Al'Imroah, Al'Imroah. 2018. "An Analysis of Students Ability in Writing Narrative Text (A Study at the Eighth Grade of SMPN 2 Tambangan in 2018/2019 Academic Year)." The State Institut for Islamic Studies.

Alviano, Firhan, Herysa Oktawati, and A. eki Kurniawan SY. 2020. "An Analysis of Students' Ability in Writing Narrative Text at X Grade in SMA N 1 Merangin Academic Year 2019/2020." English Education Program Journal 3 (3).

Ardianto, Teguh. 2016. "Developing Islamic Narrative Reading Material for Eight Grade of Islamic Junior High School in Central Jaya." Semarang State University. http://lib.unnes.ac.id.

Aulia, Evi. 2021. "Improving Students' Ability in Writing Narrative Texts Using Short Animated Stories at Class VIII of UPTD SMP Negeri 35 Sinjai." Muhammdiyah University of Makassar.

Aulia, Feni. 2019. "An Analysis of Students' Ability and Difficulty in Writing Narrative Text ( A Descriptive Research at Second Grade Students' of MA Muallimin Muhammadiyah Makassar )." Muhammadiyah University of Makassar.

Eliyawati. n.d. "Improving Students' Ability to Write Narrative Text Using Pictures." Al- Asasiyya Vol. 4. http://journal.umpo.ac.id.

Fahmi, Sri, and Cynantia Rachmijati. 2021. "Improving Students' Writing Skill Using Grammaly Application for Second Grade in Senior High School." PROJECT (Professional Journal of English Education) 4 (1): 69. https://doi.org/10.22460/project.v4i1.p69-74.

Fajrina, Novia. 2017. "Teaching Narrative Writing Through Probable Passage Strategy To Islamic Senior High School Students." Edukasi: Jurnal Pendidikan Dan Pengajaran 4 (2): 29-38.

Faridi, Abdurrachman, and Seful Bahri. 1967. "Developing English Islamic Narrative Story Reading Model in Islamic Junior High School." Angewandte Chemie International Edition, 6(11), 951-952. 7 (2): 224-43.

Fauziah, Ai Siti Nur, Lilies Youlia Friatin, and Aa SUrahmat. 2021. "Teaching Media 'Powtoon' to Assist Students' Writing Narrative Text." Journal of Development and Innovation in Language and Literature Education 1 (4): 416-22. 
Hartati, Armi. 2019. "An Analysis of Students' Ability and Dificulty in Writing Narrative Text at Sttae SMA N 1 Kampar Timur." State Islamic University of Sultan Syarif Kasim Riau Pekanbaru.

Hasibuan, Asriani, and Fitri Handayani. 2018. "An Analysis of Students Ability in Writing Narrative Text (A Study at the Eighth Grade of SMPN 2 Tambangan in 2018/2019 Academic Year)." MELT Journal 55 (56): 55-63.

Jannah, Aniatul. 2021. “The Correlation Between Students' Linguistic Intelligence and Their Writing Ability (A Correlational Study at the First Grade of Senior High School Cahaya Madani Banten Boarding School (CMBBS) Kabupaten Pandeglang)." The State Islamic University Sultan Maulana Hasanudin Banten.

Kaffah, Nisa Fadillah, Euis eti Rohaeti, and Dede Abdurrakhman. 2021. "The Study of Structure and Linguistic Rules in Writing Observation Results of Report Text at Senior High School." Journal of Language Education Reserach 4 (1): 56-63.

Khadafi, Muammar. 2017. "Teaching Narrative Writing By Using Roundtable Strategy To Islamic Junior High School Students." Edukasi: Jurnal Pendidikan Dan Pengajaran 4 (2): 57-65.

Langan, Jhon. 2006. English Skill with Readings. Seventh Ed. Mc-Graw-Hill. http://libgen.rs/.

Mufida, Ayu Zawiya. 2020. “An Analysis of Students' Ability in Writing Narrative Text by Using Collaborative Writing in the First Semester of the Tenth Grade at SMA Perintis 1 Bandar Lampung in the Academic Year 2019/2020." Raden Intan State Islamic University.

Nurhidayah, Nurhidayah. 2017. “An Analysis on Students' Ability in Writing Narrative Text at Grade IX Mts Ali Imron Medan." State Islamic University of North Sumatera.

Okome, Esther Omoakhe, Regina B Danner, and Felicia N Ofuani. 2021. “Effects of Three Instructional Strategies on Senior Secondary School Students ' Achievement in Summary Writing." Journal of Teaching and Teacher Education 9 (1).

Rahman, Tatat Hartati, Decenni Amelia, Rima Rikmasari, Resi Yugafiati, Tri Indri Hardini, and Sofyan Sauri. 2020. "The Use of Circuit Learning Model in Improving Students' Writing Skills in Elementary School." In , 3:411-18. Bandung: Universitas Pendidikan Indonesia. https://doi.org/10.2991/assehr.k.201215.091. 
Saputra, Edy, Sutikno, Ratna Wilis, Diah Handayani Tarigan, Leni Andriana, and Risna. 2021. "The Effect of Practice Methods on the Ability of Writing Text Complex Procedures of Eleventh Grade Students of Swasta Swadaya Hamparan Perak Senior High School Academic Year 2020-2021." In Proceedings of the First International Conference on Science, Technology, Engineering and Industrial Revolution (ICSTEIR 2020), 536:300-304. Atlantis Press. https://doi.org/10.2991/assehr.k.210312.048.

Sari, Ika Purnama, and Susiani Susiani. 2021. "Journal of Educational Sciences and Psychology." Journal of Educational Sciences 5 (1): 66-79.

Ya-ning, Wang. 2021. "Study on Problems and Strategies of Textual Cohesion Theory of English Writing in Senior High School." In , 268-70. https://doi.org/10.25236/icited.2021.051. 